Wahana Didaktika Vol. 16 No.2 Mei 2018 : 222-234

\title{
KEMAMPUAN MAHASISWA DALAM MEMBUAT ALAT PERAGA FISIKA MELALUI PEMBELAJARAN BERBASIS PROYEK
}

\author{
Oleh: Linda Lia \\ (Dosen Universitas PGRI Palembang) \\ Email: lindalia_burhan@yahoo.com
}

\begin{abstract}
Abstrak
Penelitian ini bertujuan untuk mendeskripsikan kemampuan mahasiswa dalam membuat alat peraga Fisika melalui pembelajaran berbasis proyek. Metode penelitian yang digunakan adalah deskriptif dengan pendekatan kualitatif. Subjek penelitian yaitu mahasiswa semester VI pada Prodi Pendidikan Fisika Universitas PGRI Palembang yang berjumlah 29 orang. Instrumen yang digunakan dalam penelitian yaitu daftar cek penilaian proyek dan dokumentasi. Hasil penelitian menunjukkan bahwa secara umum rata-rata kemampuan mahasiswa dalam membuat alat peraga Fisika melalui pembelajaran berbasis proyek diperoleh sebesar 3,53 dengan kategori baik dimana rata-rata aspek perencanaan proyek sebesar 3,75 (kategori baik), rata-rata aspek pelaksanaan proyek sebesar 3,25 (kategori cukup) dan rata-rata aspek laporan proyek sebesar 4,50 (kategori baik). Dengan demikian dapat disimpulkan bahwa melalui pembelajaran proyek mahasiswa calon guru mampu membuat alat peraga Fisika dengan baik.
\end{abstract}

Kata kunci: Alat Peraga, Pembelajaran Berbasis Proyek

\section{THE ABILITY OF STUDENTS IN MAKING PROPS OF PHYSICS THROUGH PROJECT BASED LEARNING}

\begin{abstract}
This research aimed to describe the ability of students in making Physics props through project based learning. The research method used is descriptive with a qualitative approach. The subject of research was 29 students of sixth semester students in Physics Education Program of PGRI Palembang University. Data were obtained using project assessment checklists and documentation. The results showed that in general the average ability of students in making Physics props through project based learning was 3.53 in the good category where the average aspects of project planning were 3.75 (good category), the average aspects of project implementation 3.25 (enough category) and the average aspect of the project report is 4.50 (good category). Thus it can be concluded that through project based learning, students are able to make Physics props well.
\end{abstract}

Keywords: Physics Props, Project Based Learning 
Kemampuan Mahasiswa dalam Membuat Alat Peraga....(Linda Lia)

\section{A. PENDAHULUAN}

Ilmu Fisika memiliki peranan penting dan telah membantu mempermudah segala aktivitas kehidupan manusia. Berbagai bentuk teknologi modern saat ini merupakan hasil dari penerapan ilmu Fisika. Diungkapkan Rusli (2013) bahwa Fisika mampu menjelaskan fenomena alam terutama yang berkaitan dengan perkembangan ilmu pengetahuan dan teknologi beserta peralatan yang canggih saat ini. Fisika adalah salah satu cabang ilmu sains atau IPA mengenai gejalagejala alam yang terjadi. Mubarrok \& Mulyaningsih (2014) menjelaskan bahwa Fisika merupakan pengetahuan yang disusun berdasarkan fakta, fenomena alam, hasil pemikiran dan eksperimen. Pada mata pelajaran Fisika mengharuskan peserta didik memahami, mengerti serta mengaplikasikannya dalam kehidupan nyata (Lubis dkk, 2015).

Berdasarkan kenyataan di lapangan bahwa peserta didik masih menganggap mata pelajaran Fisika merupakan mata pelajaran yang sulit. Hal ini disebabkan karena dalam pembelajaran Fisika peserta didik hanya menghafalkan rumus tanpa memahami maknanya dan tidak mampu menerapkannya dalam berbagai situasi aplikatif (Fikriyah dkk, 2015). Selain itu, bentuk hands on activity (aktif dalam bertindak) dalam proses pembelajaran Fisika bagi peserta didik kurang maksimal dimana sebanyak 88\% peserta didik mengatakan bahwa pembelajaran Fisika yang sering dialami adalah dengan metode ceramah (Azizah dkk, 2015). Menurut Ellianawati \& Subali (2010) bahwa belajar Fisika yang ideal adalah dengan doing sciences atau melakukan sains karena peserta didik memperoleh pengetahuan fisis tentang suatu obyek dengan mengerjakan atau bertindak terhadap objek itu melalui indera. Oleh sebab itu, hands on activity dan doing sciences yang mengarah pada proses penemuan sangat diperlukan agar peserta didik mampu mempelajari dan memahami Fisika dan aplikasinya dengan baik.

Keterbatasan peralatan praktikum dan demonstrasi juga menjadi penyebab kurangnya aktifitas pembelajaran berorientasi penemuan khususnya kegiatan di laboratorium. Padahal, proses ilmiah dan pengembangan sikap ilmiah yang 
dialami peserta didik melalui kegiatan praktikum di laboratorium dan kegiatan penemuan lainnya menjadi bagian yang tidak terpisahkan untuk memahami Fisika. Sehingga, dari kegiatan tersebut peserta didik dapat memperoleh serangkaian pengalaman dan pengetahuan Fisika. Seiring dengan pendapat Sambada (2012) bahwa Fisika tidak hanya ditandai oleh adanya kumpulan fakta atau produk saja melainkan juga ditandai munculnya metode dan sikap ilmiah. Dijelaskan juga bahwa pelajaran Fisika tidak cukup hanya mempelajari produk tetapi menekankan bagaimana produk itu diperoleh, baik sebagai proses ilmiah maupun pengembangan sikap ilmiah peserta didik (Prihatiningtyas dkk, 2013).

Keterbatasan peralatan praktikum tersebut mengakibatkan seorang guru dituntut untuk kreatif dalam merancang pembelajaran Fisika. Permenpan nomor 16 tahun 2009 tentang jabatan fungsional guru dan angka kredit pada bab V pasal 11 menyebutkan pengembangan profesi guru dapat dilakukan melalui pengembangan karya inovatif salah satunya yaitu menemukan teknologi tepat guna termasuk membuat/memodifikasi alat peraga/praktikum (Widiyatmoko \& Pamelasari, 2012). Sesuai dengan Permenpan tersebut bahwa kemampuan mahasiswa sebagai calon guru untuk kreatif dalam membuat alat peraga sangat dibutuhkan. Mahasiswa calon guru tersebut akan mengajar di sekolah yang fasilitas laboratoriumnya belum tentu lengkap untuk setiap sekolah baik di perkotaan atau desa. Jika guru tidak kreatif akan sulit melaksanakan kegiatan pembelajaran khususnya demonstrasi atau praktikum pada mata pelajaran Fisika sesuai tuntutan Kurikulum 2013 karena seperti yang telah dijelaskan sebelumnya bahwa untuk mempelajari Fisika maka peserta didik harus terlibat dalam bertindak, mengalami proses penemuan, melaksanaan proses ilmiah, dan membentuk sikap ilmiah sehingga peserta didik bisa mengkonstruk pengetahuannya sendiri.

Menurut Kristanti dkk (2016) bahwa pembelajaran Fisika saat ini sering menggunakan pendekatan pembelajaran yang berpusat pada guru, tetapi berdasarkan kurikulum yang berlaku sekarang pendekatan pembelajaran yang 
Kemampuan Mahasiswa dalam Membuat Alat Peraga....(Linda Lia)

berpusat pada guru (teacher centered learning) dituntut untuk merubahnya menjadi pendekatan pembelajaran yang berpusat pada peserta didik (student centered learning). Pendekatan pembelajaran yang berpusat pada peserta didik yang sesuai dengan proses pembelajaran Fisika yaitu menggunakan pendekatan saintifik.

Pendekatan saintifik adalah proses pembelajaran yang dirancang sedemikian rupa agar peserta didik secara aktif menkonstruksi konsep, hukum atau prinsip melalui tahapan-tahapan mengamati (untuk mengidentifikasi atau menemukan masalah), merumuskan masalah, mengajukan atau merumuskan hipotesis, mengumpulkan data dengan berbagai teknik, menganalisis data, menarik kesimpulan dan mengomunikasikan konsep, hukum atau prinsip yang ditemukan (Machin, 2014). Sebagian besar kalangan termasuk para pakar memandang pendekatan saintifik sebagai discovery method atau metode penemuan yang sesuai dengan pengembangan kompetensi yang diperlukan untuk menghadapi abad 21 (Kustijono \& HM, 2014). Salah satu model pembelajaran yang menggunakan pendekatan saintifik yaitu model pembelajaran berbasis proyek (project based learning model).

Model pembelajaran berbasis proyek merupakan pembelajaran yang berpusat pada proses, relatif berjangka waktu, berfokus pada masalah, unit pembelajaran bermakna dengan memadukan konsep-konsep dari sejumlah komponen baik itu pengetahuan, disiplin ilmu atau lapangan (Kristanti dkk, 2016). Model ini sangat cocok untuk diterapkan dalam pembelajaran karena melibatkan peserta didik untuk bertindak aktif dalam proses penemuan sehingga peserta didik bisa dengan sendirinya mengkonstruk pengetahuan dan pengalamannya.

Hasil penelitian menunjukkan bahwa dengan menggunakan pembelajaran berbasis proyek mahasiswa telah mampu mengembangkan dan menghasilkan alat peraga IPA dengan baik (Widiyatmoko \& Pamelasari, 2012). Pembelajaran berbasis proyek membuat ensiklopedia Ilmu Pengetahuan Alam (IPA) dapat 
meningkatkan Academic Skill pada mahasiswa (Purbosari, 2016). Model pembelajaran berbasis proyek memiliki peranan yang cukup berarti dalam proses pembelajaran sehingga sangat membantu peserta didik dalam memudahkan memahami pelajaran dan pada akhirnya dapat meningkatkan keterampilan proses sains dan motivasi belajar (Salmi dkk, 2017). Terdapat perbedaan yang signifikan antara motivasi belajar fisika yang diajar dengan pembelajaran berbasis proyek dan yang diajar dengan pembelajaran tanpa berbasis proyek pada peserta didik kelas XI MIPA SMA Negeri 2 Sengkang (Rahmini dkk, 2015).

Berdasarkan uraian di atas bahwa melalui model pembelajaran berbasis proyek diharapkan dapat membantu mahasiswa dalam merencanakan dan membuat alat peraga dengan baik sehingga dapat menjadi alternatif dalam mengatasi permasalahan pembelajaran Fisika di sekolah menengah. Oleh karena itu, sangat penting untuk mengetahui kemampuan mahasiswa calon guru membuat alat peraga Fisika melalui pembelajaran berbasis proyek. Adapun tujuan dari penelitian ini adalah untuk mendeskripsikan kemampuan mahasiswa calon guru membuat alat peraga Fisika melalui pembelajaran berbasis proyek.

\section{B. METODOLOGI PENELITIAN}

Metode penelitian yang digunakan adalah deskriptif dengan pendekatan kualitatif. Metode ini dipilih untuk menggambarkan atau mendeskripsikan kemampuan mahasiswa calon guru membuat alat peraga Fisika melalui pembelajaran berbasis proyek. Penelitian dilakukan pada mahasiswa Program Studi Pendidikan Fisika semester genap tahun ajaran 2017/2018. Subjek penelitian berjumlah 29 orang mahasiswa yang mengambil mata kuliah Laboratorium Fisika II.

Adapun prosedur yang dilakukan dalam penelitian seperti yang ditunjukkan pada gambar 1 berikut.

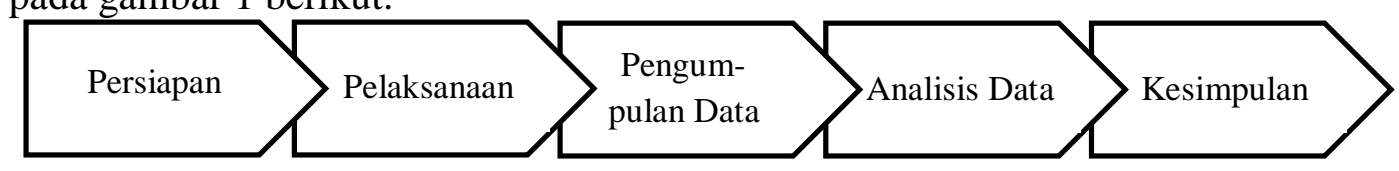




\section{Gambar 1. Prosedur Penelitian}

Alat pengumpul data dalam penelitian ini menggunakan checklist/daftar cek penilaian proyek dan dokumentasi. Data yang diperoleh kemudian dianalisis dan selanjutnya dikelompokkan berdasarkan kategori hasil penilaian proyek seperti tabel 1 berikut.

\section{Tabel 1. Kategori Hasil Penilaian Proyek}

\begin{tabular}{cc}
\hline Skor & Kategori \\
\hline$>4,20$ s.d. 5,00 & Sangat Baik (SB) \\
$>3,40$ s.d. 4,20 & Baik (B) \\
$>2,60$ s.d. 3,40 & Cukup (C) \\
$>1,80$ s.d. 2,60 & Kurang (K) \\
1,00 s.d. 1,80 & Gagal (G) \\
\hline (Modifikasi Widoyoko, 2012) &
\end{tabular}

\section{HASIL DAN PEMBAHASAN}

Penelitian ini telah dilaksanakan pada mahasiswa yang mengambil mata kuliah Laboratorium Fisika II yang seluruhnya berjumlah 29 orang pada mahasiswa Program Studi Pendidikan Fisika Universitas PGRI Palembang semester genap tahun ajaran 2017/2018. Mahasiswa dibagi menjadi 12 kelompok dimana masing-masing kelompok terdiri dari 2 atau 3 orang.

Proses pembelajaran mengikuti langkah-langkah pembelajaran berbasis proyek yaitu penentuan pertanyaan mendasar, menyusun perencanaan proyek, menyusun jadwal, monitoring, menguji hasil, dan evaluasi pengalaman. Selama proses pembelajaran berlangsung penilaian dimulai dari awal pembelajaran sampai dengan akhir pembelajaran menggunakan rubrik penilaian proyek.

Rubrik penilaian proyek terdiri dari 3 aspek yaitu perencanaan, pelaksanaan, dan laporan proyek (Kemdikbud, 2013). Komponen perencanaan yaitu persiapan dan rumusan judul. Komponen pelaksanaan yaitu sistematika penulisan, keakuratan sumber data/informasi, kuantitas sumber data, analisis data, dan 
penarikan kesimpulan. Komponen laporan proyek yaitu performans dan presentasi/penguasaan.

Pada pembelajaran berbasis proyek dalam penelitian ini dihasilkan alat peraga yang telah dibuat oleh mahasiswa calon guru. Adapun judul alat peraga yang dihasilkan mahasiswa calon guru melalui pembelajaran berbasis proyek yaitu: 1) kemagnetan, 2) gelombang transversal dan longitudinal, 3) listrik, 4) perpindahan kalor secara konveksi, 5) cermin datar, 6) hukum Boyle, 7) lift hidrolik pada hukum Pascal, 8) rangkaian listrik dan hambatan listrik, 9) hukum pemantulan cahaya, 10) gelombang bunyi, 11) hukum Bernouli, dan 12) motor listrik sederhana.

Azizah dkk (2015) mengungkapkan bahwa pembelajaran Fisika memiliki tujuan diantaranya mengembangkan pengetahuan, pemahaman, dan kemampuan analisis peserta didik terhadap lingkungan dan sekitarnya agar peserta didik tidak hanya menguasai konsep tetapi juga mampu menerapkan konsep yang telah mereka pahami dalam penyelesaian masalah Fisika. Ilmu Fisika banyak mengkaji materi yang sifatnya abstrak dan mikroskopik sehingga materi Fisika tidak cukup hanya dibayangkan dan disampaikan dengan ceramah saja. Untuk itu, penggunaan alat peraga sangat penting dalam pembelajaran Fisika di sekolah menengah.

Sambada (2012) mengungkapkan bahwa seorang guru harus menguasai kompetensi antara lain kemampuan mengaplikasikan berbagai teori belajar dalam pengajaran, kemampuan memilih dan menerapkan metode mengajar yang efektif dan efisien, dan yang paling penting kekreatifan guru untuk mampu melibatkan peserta didik berpartisipasi aktif dalam pembelajaran. Selain itu, Arsyad (2011) mengungkapkan bahwa pemilihan model dan media pembelajaran merupakan unsur penting dalam proses pembelajaran. Oleh sebab itu, diperlukan kreatifitas guru dalam membuat media pembelajaran terutama media objek yang disebut alat peraga.

Alat peraga merupakan suatu media fisik pendidikan yang digunakan untuk menyampaikan isi materi pengajaran yang dapat merangsang peserta didik untuk 
Kemampuan Mahasiswa dalam Membuat Alat Peraga....(Linda Lia)

belajar baik tercetak maupun audio-visual (Abdullah dkk, 2011). Alat peraga pendidikan disusun berdasarkan prinsip bahwa pengetahuan yang ada pada setiap manusia itu diterima atau ditangkap melalui panca indera dimana semakin banyak indera yang digunakan untuk menerima sesuatu maka semakin banyak dan semakin jelas pula pengertian atau pengetahuan yang diperoleh sehingga mempermudah persepsi (Pramesty \& Prabowo, 2013). Penggunaan alat peraga dapat mempermudah dalam mengajarkan konsep materi Fisika yang sifatnya abstrak. Oleh karena itu, mahasiswa sebagai calon guru harus bisa kreatif dalam membuat dan merancang alat peraga Fisika yang akan berguna saat mengajar di sekolah menengah nantinya.

Pada penelitian ini, kemampuan mahasiswa calon guru dalam membuat alat peraga Fisika melalui pembelajaran berbasis proyek dianalisis mulai dari perencanaan, pelaksanaan, dan sampai dengan akhir proyek. Berikut hasil penilaian proyek yang telah dilakukan seperti terlihat pada tabel 3 berikut.

Tabel 3. Hasil Penilaian Proyek Mahasiswa

\begin{tabular}{|c|c|c|c|c|c|c|}
\hline \multirow[b]{2}{*}{ Kelompok } & \multicolumn{3}{|c|}{ Skor Aspek } & \multirow[b]{2}{*}{ Total } & \multirow[b]{2}{*}{ Rerata } & \multirow[b]{2}{*}{ Kategori } \\
\hline & Perencanaan & Pelaksanaan & $\begin{array}{c}\text { Laporan } \\
\text { Proyek }\end{array}$ & & & \\
\hline 1 & 4,00 & 3,40 & 3,50 & 10,90 & 3,63 & Baik \\
\hline 2 & 4,50 & 3,40 & 3,50 & 11,40 & 3,80 & Baik \\
\hline 3 & 2,50 & 3,20 & 3,00 & 8,70 & 2,90 & Cukup \\
\hline 4 & 4,00 & 3,20 & 4,50 & 11,70 & 3,90 & Baik \\
\hline 5 & 4,50 & 4,20 & 4,00 & 12,70 & 4,23 & Sangat Baik \\
\hline 6 & 3,50 & 3,20 & 4,00 & 10,70 & 3,57 & Baik \\
\hline 7 & 5,00 & 3,60 & 3,50 & 12,10 & 4,03 & Baik \\
\hline 8 & 4,00 & 2,60 & 2,50 & 9,10 & 3,03 & Cukup \\
\hline 9 & 3,50 & 3,60 & 4,00 & 11,10 & 3,70 & Baik \\
\hline 10 & 4,00 & 3,40 & 4,00 & 11,40 & 3,80 & Baik \\
\hline 11 & 3,00 & 2,40 & 2,00 & 7,40 & 2,47 & Kurang \\
\hline 12 & 2,50 & 2,80 & 4,50 & 9,80 & 3,27 & Cukup \\
\hline Rerata & 3,75 & 3,25 & 4,50 & & 3,53 & Baik \\
\hline
\end{tabular}

Berdasarkan tabel di atas diketahui bahwa rata-rata kemampuan mahasiswa secara keseluruhan dalam membuat alat peraga Fisika melalui pembelajaran berbasis proyek sebesar 3,53 dengan kategori baik. Rata-rata aspek perencanaan 
proyek sebesar 3,75 dengan kategori baik. Rata-rata aspek pelaksanaan proyek sebesar 3,25 dengan kategori cukup. Kemudian, rata-rata aspek laporan proyek sebesar 4,50 dengan kategori baik.

Persentase berdasarkan kategori kemampuan mahasiswa dalam membuat alat peraga Fisika melalui pembelajaran berbasis proyek dapat dilihat pada gambar 2 sebagai berikut.

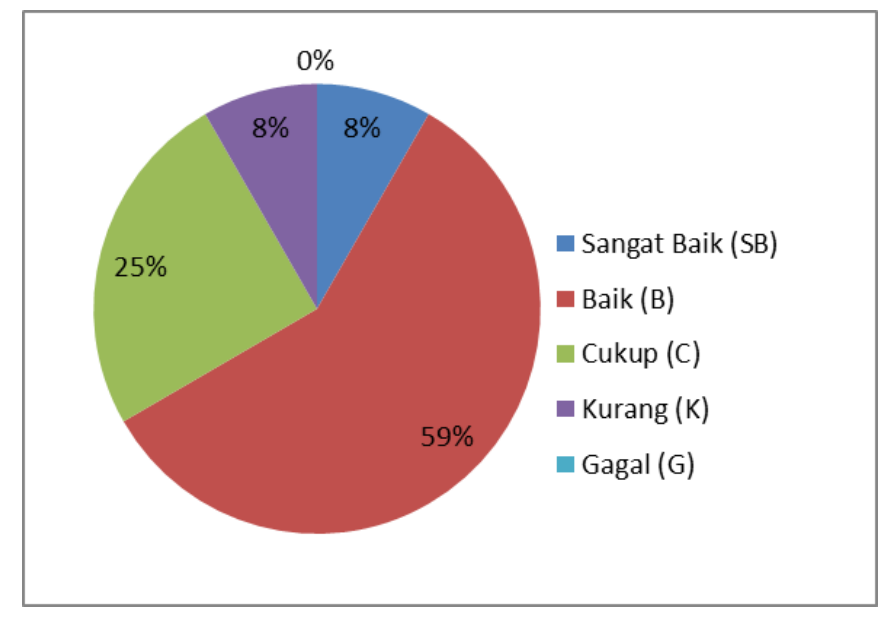

Gambar 2. Hasil Penilaian Proyek Mahasiswa

Berdasarkan gambar di atas dapat diketahui bahwa persentase kemampuan mahasiswa dalam membuat alat peraga Fisika melalui pembelajaran berbasis proyek. Sebanyak 1 kelompok atau 8\% memiliki kemampuan dengan kategori sangat baik. Sebanyak 7 kelompok atau 59\% memiliki kemampuan dengan kategori baik. Sebanyak 3 kelompok atau 25\% memiliki kemampuan dengan kategori cukup. Sebanyak 1 kelompok atau 8\% memiliki kemampuan dengan kategori kurang.

Secara umum rata-rata kemampuan mahasiswa dalam membuat alat peraga Fisika melalui pembelajaran berbasis proyek sebesar 3,53 dengan kategori baik. Sehingga dapat dikatakan bahwa melalui pembelajaran proyek mahasiswa mampu membuat alat peraga Fisika dengan baik. Penelitian yang dilakukan oleh Widiyatmoko \& Pamelasari (2012) menunjukkan bahwa dengan menggunakan 
pembelajaran berbasis proyek mahasiswa telah mampu mengembangkan dan menghasilkan alat peraga IPA dengan baik.

Mengingat bahwa masing-masing peserta didik memiliki gaya belajar yang berbeda, maka pembelajaran berbasis proyek memberikan kesempatan kepada para peserta didik untuk menggali konten (materi) dengan menggunakan berbagai cara yang bermakna bagi dirinya, dan melakukan eksperimen secara kolaboratif (Kemdikbud, 2013). Mahasiswa calon guru juga memiliki gaya belajar yang berbeda. Oleh sebab itu, sangat tepat menggunakan model pembelajaran berbasis proyek dalam membuat alat peraga Fisika.

Melalui pembelajaran berbasis proyek, peserta didik dituntut untuk dapat memilih topik dan proyek presentasi/produk, menghasilkan produk akhir, dan memecahkan masalah yang terkait dengan dunia nyata, serta melibatkan berbagai disiplin ilmu (Rachmawati dkk, 2017). Model pembelajaran berbasis proyek memiliki keunggulan dari karakteristiknya yaitu membantu peserta didik merancang proses untuk menentukan sebuah hasil, melatih peserta didik bertanggung jawab dalam mengelola informasi yang dilakukan pada sebuah proyek dan yang terakhir peserta didik menghasilkan sebuah produk nyata hasil peserta didik itu sendiri yang kemudian dipresentasikan dalam kelas (Amirudin dkk, 2015).

Adapun kelemahan model pembelajaran berbasis proyek yaitu model ini memiliki durasi belajar yang cukup panjang. Hal ini ditegaskan oleh Rais (2010) bahwa model pembelajaran berbasis proyek lebih menekankan pada kegiatan belajar yang relatif berdurasi panjang, holistik-interdisipliner, berpusat pada pembelajar, dan terintegrasi dengan praktik dan isu-isu dunia nyata.

\section{SIMPULAN}

Secara umum rata-rata kemampuan mahasiswa calon guru dalam membuat alat peraga Fisika melalui pembelajaran berbasis proyek diperoleh sebesar 3,53 
dengan kategori baik dimana rata-rata aspek perencanaan proyek sebesar 3,75 (kategori baik), rata-rata aspek pelaksanaan proyek sebesar 3,25 (kategori cukup) dan rata-rata aspek laporan proyek sebesar 4,50 (kategori baik). Sehingga, berdasarkan hasil analisis dan pembahasan dapat disimpulkan bahwa melalui pembelajaran proyek mahasiswa calon guru mampu membuat alat peraga Fisika dengan baik.

\section{DAFTAR PUSTAKA}

Abdullah, Oviana, W., \& Khatimah, H. 2011. Penggunaan Alat Peraga dari Bahan Bekas dalam Menjelaskan Sistem Respirasi Manusia di MAN Sawang Kabupaten Aceh Selatan. Jurnal Ilmiah Pendidikan Biologi, 3 (2), 51-55.

Amirudin, A. $d k k$. 2015. Pengaruh Model Pembeajaran Berbasis Proyek Terhadap Kemampuan Menulis Karya Ilmiah Geografi Siswa SMA. Jurnal Pendidikan Geografi. 20 (1).

Arsyad, A. 2011. Media Pembelajaran. Jakarta: PT. Raja Grafindo Persada.

Azizah, R., Yuliati, L., \& Latifah, E. 2015. Kesulitan Pemecahan Masalah Fisika pada Siswa SMA. Jurnal Penelitian Fisika dan Aplikasinya, 5 (2), 44-50.

Ellianawati, \& Subali, B. 2010. Penerapan Model Praktikum Problem Solving Laboratory sebagai Upaya untuk Memperbaiki Kualitas Pelaksanaan Praktikum Fisika Dasar. Jurnal Pendidikan Fisika Indonesia, (6), 90-97.

Fikriyah, M., Indrawati, \& Gani, A. A. 2015. Model Pembelajaran Berbasis Proyek (Project Based Learning) disertai Media Audio-Visual dalam Pembelajaran Fisika di SMAN 4 Jember. Jurnal Pembelajaran Fisika, 4 (2), 181-186.

Kemdikbud. 2013. Materi Pelatihan Guru Implementasi Kurikulum 2013 SMP/MTs IPA. Jakarta: Kemdikbud.

Kristanti, Y. D., Subiki, \& Handayani, R. D. 2016. Model Pembelajaran Berbasis Proyek (Project Based Learning Model) pada Pembelajaran Fisika di SMA. Jurnal Pembelajaran Fisika, 5 (2), 122-128.

Kustijono, R., \& HM, E. W. 2014. Pandangan Guru terhadap Pelaksanaan Kurikulum 2013 dalam Pembelajaran Fisika SMK di Kota Surabaya. Jurnal Pendidikan Fisika dan Aplikasinya, 4 (1), 1-14.

Lubis, F. M., Bukit, N., \& Harahap, M. B. 2015. Efek Model Pembelajaran Kooperatif Tipe NHT (Numbered Heads Together) Menggunakan Media 
Kemampuan Mahasiswa dalam Membuat Alat Peraga....(Linda Lia)

Simulasi PhET dan Aktivitas terhadap Hasil Belajar Siswa. Jurnal Tabularasa PPs UNIMED, 12 (1), 31-40.

Machin, A. 2014. Implementasi Pendekatan Saintifik, Penanaman Karakter, dan Konservasi pada Pembelajaran Materi Pertumbuhan. Jurnal Pendidikan IPA Indonesia , 3 (1), 28 - 35.

Mubarrok, M. F., \& Mulyaningsih, S. 2014. Penerapan Pembelajaran Fisika pada Materi Cahaya dengan Media PhET Simulations untuk Meningkatkan Pemahaman Konsep Siswa di SMP. Jurnal Inovasi Pendidikan Fisika, 3 (1), 76-80.

Pramesty, R. I., \& Prabowo. 2013. Pengembangan Alat Peraga KIT Fluida Statis sebagai Media Pembelajaran pada Sub Materi Fluida Statis di Kelas XI IPA SMA Negeri 1 Mojosari, Mojokerto. Jurnal Inovasi Pendidikan Fisika, 2 (3), 70-74.

Prihatiningtyas, S., Prastowo, T., \& Jatmiko, B. 2013. Implementasi Simulasi PhET dan KIT Sederhana untuk Mengajarkan Keterampilan Psikomotor Siswa pada Pokok Bahasan Optik. Jurnal Pendidikan IPA Indonesia, 2 (1), 18-22.

Purbosari, P. M. 2016. Pembelajaran Berbasis Proyek Membuat Ensiklopedia Ilmu Pengetahuan Alam (IPA) untuk Meningkatkan. Scholaria, 6 (3), 231238.

Rachmawati, I. N., Gani, A. A., \& Indrawati. 2017. Implementasi Model Pembelajaran Berbasis Proyek (Project Based Learning) dengan Analisis Kejadian Fisika dalam Pembelajaran Fisika di SMA. Jurnal Pembelajaran Fisika, 6 (2), 189-195.

Rahmini, Muris, \& Amin, B. D. 2015. Pengaruh Pembelajaran Berbasis Proyek terhadap Motivasi Belajar Fisika Peserta Didik Kelas XI MIPA SMA Negeri 2 Sengkang. Jurnal Sains dan Pendidikan Fisika, 11 (2), 161-168.

Rais, M. 2010. Project Based Learning; Inovasi Pembelajaran yang Berorientasi Soft skills. Seminar Nasional Pendidikan Teknologi dan Kejuruan Fakultas Teknik Universitas Negeri Surabaya (pp. 1 - 17). Surabaya: Universitas Negeri Surabaya.

Rusli, A. 2013. Pendidikan Fisika untuk Abad ke-21: Kesadaran, Wawasan, Kedalaman, Etika. Jurnal Fisika Indonesia, 17 (50), 16-19.

Salmi, N., Azis, A., \& Patandean, A. J. 2017. Penerapan Model Pembelajaran Berbasis Proyek terhadap Motivasi Belajar Fisika dan Keterampian Proses Sains Peserta Didik SMAN 4 Makassar. Jurnal Sains dan Pendidikan Fisika, 13 (3), 238-247. 
Sambada, D. 2012. Peranan Kreativitas Siswa terhadap Kemampuan Memecahkan Masalah Fisika dalam Pembelajaran Kontekstual. Jurnal Penelitian Fisika dan Aplikasinya, 2 (2), 37-47.

Widiyatmoko, A., \& Pamelasari, S. D. 2012. Pembelajaran Berbasis Proyek untuk Mengembangkan Alat Peraga IPA dengan Memanfaatkan Bahan Bekas Pakai. Jurnal Pendidikan IPA Indonesia, 1 (1), 51-56.

Widoyoko, E.P. 2012. Teknik Penyusunan Instrumen. Yogyakarta: Pustaka Belajar. 